\section{Effect of Ginkgo biloba on the labeling of blood elements with technetium-99m: in vitro study}

\section{Silvana Ramos Farias Moreno 1,2 ; Gláucio Diré Feliciano Rosimeire Souza Freitas ${ }^{2}$; Miguel Benito Farah ${ }^{1}$; Guilherme Lima Laurentino-Filho'; Emely Kazan Rocha ${ }^{3}$; Roberto Levi Cavalcanti Jales ${ }^{4}$; Mario Bernardo Filho ${ }^{2 \star}$}

${ }^{1}$ Universidade Federal Fluminense, Departamento de Patologia; Niterói, RJ

${ }^{2}$ Universidade do Estado do Rio de Janeiro, Instituto de Biologia Roberto Alcantara Gomes, Departamento de Biofísica e Biometria, 20551-030, Rio de Janeiro, RJ

${ }^{3}$ Universidade do Estado do Rio de Janeiro, Instituto de Biologia Roberto Alcantara Gomes, Departamento Biologia Celular e Genética, Rio de Janeiro, RJ

${ }^{4}$ Universidade Federal do Rio Grande do Norte, Faculdade de Farmácia, Natal, RN, Brasil

bernardo@uerj.br

\section{Abstract}

Ginkgo biloba is the phytoterapic most used in popular medicine in the treatment of cerebral senescence. Red blood cells (RBC) labeled with technetium-99m (Tc-99m) is used for several evaluations in nuclear medicine. This labeling depends on a reducing agent, usually the stannous ion. Any drug, which alters the labeling of the tracer, could be expected to modify the disposition of the radiopharmaceutical. We have evaluated the influence of the Ginkgo biloba extract on the labeling of RBC and plasma proteins with Tc-99m. Blood was withdrawn and incubated with Ginkgo biloba extract $(0 ; 0.004 ; 0.04 ; 0.4 ; 4 ; 20$ and $40 \mathrm{mg} / \mathrm{ml})$. Stannous chloride $(1.2 \mathrm{ml} / \mathrm{ml})$ was added and, then, Tc-99m was added. Plasma (P) and blood cells (RBC) were isolated, also precipitated with trichloroacetic acid and soluble (SF) and insoluble fractions (IF) separated. The analysis of the results shows that there is a decrease in the radioactivity (from $97.7 \pm 0.7$ to $49.5 \pm 3.9 \%)$ in $\mathrm{RBC}$ with the drug $(4 \mathrm{mg} / \mathrm{ml})$. In the labeling process of $\mathrm{RBC}$ with $\mathrm{Tc}-99 \mathrm{~m}$, the stannous and pertechnetate ions pass though the membrane, so, we suggest that the Ginkgo biloba effect can be explained by (i) an inhibition of the transport of these ions, (ii) damage in membrane, (iii) competition with the cited ions for the same binding sites, or (iv) possible generation of reactive oxygen species that could oxidize the stannous ion.

The use of medicinal plants or natural products has increased in the last decades all over the world. Ginkgo biloba is a gymnosperm considered a "living fossil" and is the phytoterapic most used in popular medicine in the treatment of cerebral senescence. Ginkgo biloba extract has important antioxidant properties due to probably to the presence of flavonoids $\mathrm{s}^{1,2,3}$.

In nuclear medicine, red blood cells (RBC) are usually labeled with technetium-99m (Tc-99m) and used as radiopharmaceutical in studies of the cardiac function, volemia and detection of gastrointestinal bleeding sites. Plasma proteins are also labeled with Tc-99m and used for evaluation of lung perfusion and location of placenta ${ }^{4,5}$. These labeling techniques involve the pre-tinning of the blood constituents with stannous ions, followed by exposure to Tc-99m, as sodium pertechnetate, which is reduced within of the cell and remains trapped intracellularly by the binding in the beta chain of hemoglobin ${ }^{4,5,6}$.

It is reported that many substances can alter the labeling of blood elements with Tc- $99 \mathrm{~m}^{7}$. There are some studies about the effect of the medicinal plants (Thuya occidentalis, Nicotiana tabacum, Peumus boldus, Maytenus ilicifolia) on the labeling of $\operatorname{RBC}(6,7,8,9,10)$. We have studied the effect of Ginkgo biloba extract on the labeling of RBC and plasma proteins with Tc-99m.

The analysis of the results (Table 1) indicates that there is a significant decrease $(p<0.05)$ on the uptake of Tc-99m by the red blood cells with the concentrations from 0.4 up to 20 $\mathrm{mg} / \mathrm{ml}$ of the extract of Ginkgo biloba. The analysis of the results also indicates that there is a significant decrease $(\mathrm{p}<0.05)$ in the fixation of Tc-99m in insoluble fractions of the blood cells when the concentrations from 0.4 up to $40 \mathrm{mg} / \mathrm{ml}$ of the extract.

Table 1. Effect of Ginkgo biloba extract on the labeling of red blood cells (RBC) and on the insoluble fraction of the red blood cells (IF-RBC) and plasma (IF-P) with Tc-99m

\begin{tabular}{l|l|l|l}
\hline $\begin{array}{l}\text { Ginkgo biloba } \\
\text { concentration }(\mathrm{mg} / \mathrm{ml})\end{array}$ & RBC & IF-RBC & IF-P \\
\hline 0.00 (control) & $97.7 \pm 0.7$ & $87.1 \pm 2.8$ & $73.8 \pm 6.6$ \\
\hline 0.004 & $97.4 \pm 0.3$ & $88.0 \pm 3.5$ & $69.0 \pm 3.2$ \\
\hline 0.04 & $96.3 \pm 0.1$ & $88.7 \pm 1.8$ & $75.3 \pm 0.5$ \\
\hline 0.4 & $62.3 \pm 3.1$ & $68.7 \pm 1.0$ & $27.9 \pm 0.7$ \\
\hline 4.0 & $49.5 \pm 3.9$ & $32.8 \pm 10.7$ & $11.6 \pm 3.0$ \\
\hline 20.0 & $53.7 \pm 0.9$ & $32.2 \pm 2.9$ & $8.8 \pm 0.1$ \\
\hline $40 . .0$ & $48.1 \pm 15.5$ & $23.5 \pm 12.1$ & $8.3 \pm 0.7$ \\
\hline
\end{tabular}

Samples of heparinized blood were incubated with different concentrations of Ginkgo biloba extract (0.004; $0.04 ; 0.4 ; 4 ; 20$ and $40 \mathrm{mg} / \mathrm{ml})$. A sample of heparinized whole blood was incubated with saline solution $(\mathrm{NaCl} 0.9 \%)$ as control. Then, stannous chloride $(1.2 \mathrm{mg} / \mathrm{ml})$ and $\mathrm{Tc}-$ $99 \mathrm{~m}$, as sodium pertechnetate were added. The radioactivity in $\mathrm{P}, \mathrm{RBC}$, IF-C and IF-P were determined in a well counter and the percent of radioactivity (\% ATI) was calculated. A statistical analysis (ANOVA test, $\mathrm{n}=10$ ) was used to compare the results.

Although the exact mechanism of the effect of Ginkgo biloba $(40-0.4 \mathrm{mg} / \mathrm{ml})$ on the labeling of RBC, IF-RBC and IF$\mathrm{P}$ is not elucidated, we suggest that it might be explained by (i) a direct inhibition (chelating action) of the referred ions or (ii) by 
damages induced in plasma membrane; (iii) by competition of the cited ions to the same bindings sites; or (iv) by possible generation of reactive oxygen species that could oxidize the stannous ion.

\section{Material and Methods}

Decoction of a commercial Ginkgo biloba extract (Farmacutis RJ Brazil/ China Jiangsu Medicines and Health Products Lot no GB 001128) with $24 \%$ of active principle was prepared with $0.9 \% \mathrm{NaCl}$. Heparinized whole blood was withdrawn from Wistar rats. Blood samples $(0.5 \mathrm{ml})$ were incubated, and gently mixed, with $100 \mathrm{ml}$ of different dilutions of the Ginkgo biloba extract ( $0.004 ; 0.04 ; 0.4 ; 4 ; 20$ and $40 \mathrm{mg} /$ $\mathrm{ml}$ ) for $60 \mathrm{~min}$. After this period of time, $0.5 \mathrm{ml}$ of a recently prepared stannous chloride solution $(1.2 \mathrm{mg} / \mathrm{ml})$ was added and the incubation continued for $60 \mathrm{~min}$ with this reducing agent. Then, $100 \mathrm{ml}$ of Tc-99m, recently milked from a 99Molibdenium/ 99mTechnetium generator (Instituto de Pesquisas Energéticas e Nucleares, Comissão Nacional de Energia Nuclear, São Paulo, Brazil) were added and the incubation was continued for another $10 \mathrm{~min}$. These samples were centrifuged and plasma $(\mathrm{P})$ and blood cells (RBC) were separated.

Samples $(20 \mathrm{ml})$ of $\mathrm{P}$ and $\mathrm{RBC}$ were precipitated with 1 $\mathrm{ml}$ of trichloroacetic acid (TCA) (5\%) and soluble (SF) and insoluble fractions (IF) were separated. The radioactivity in $\mathrm{P}$, RBC, IF-P, SF-P, IF-RBC and SF-RBC were determined in a well counter (Clinigamma, gamma counter, LKB, Wallac, Finland). After that, the percent of radioactivity (\% ATI) was calculated, as previously described ${ }^{6,9}$. A statistical analysis (ANOVA test and Tukey-Kramer test) was employed to compare the experimental data.

\section{References}

${ }^{1}$ Yucheng N, Baolu Z, Jingwu H, Wenjuan X. Preventive effect of Ginkgo biloba extract on apoptosis in rat cerebellar neuronal cells induced by hydroxyl radicals. Neuroscience Letters 1996; 214: $115-18$

${ }^{2}$ Diamond BJ, Shiflet SC, Fewel N, Matheis RJ; Noskin O, Richards JA. Ginkgo biloba extract: mechanisms and clinical indications. Archives Physical Medicine and Rehabilitation 2000; 81:668-78

${ }^{3}$ Galluzzi S, Zanetti G, Binetti G, Trabucchi M, Frisoni GB. Coma in patient with Alzheimer' s disease takinglow doses the Ginkgo biloba. Journal Neurology Neurosurgery Psychiatry 2000; 68: 679-80

${ }^{4}$ Early PJ, Sodee DB. Principles and Practice of Nuclear Medicine, Mosby YearBook, 1995; 887p

${ }^{5}$ Harbert JC, Eckelman, WC, Neumann, RD. Nuclear Medicine Diagnosis and Therapy, Thieme Medical Publishers, Inc., New York, 1996

${ }^{6}$ Bernardo-Filho M, Gutfilen B, Maciel OS. Effect of different anticoagulants on the labeling of red blood cells and plasma proteins with technetium-99m. Nuclear Medicine Communications 1994; 15: 730-34

${ }^{7}$ Sampson CB. Complications and difficulties in radiolabeling blood cells: A review. Nuclear Medicine Comunications 1996; 17: 648-58

${ }^{8}$ Billinghurst MW, Jette D. In vitro kinetics of red blood cell labeling with $99 \mathrm{mTc}$ in association with stannous pyrophosphate. Journal of Radioanalitical Chemistry 1980; 59:579-84

${ }^{9}$ Vidal MV, Gutfilen B, Fonseca LMB, Bernardo-Filho M. Influence of tobacco on labeling of red blood cells and plasma proteins with technetium-99m. Journal of Experimental and Clinical Cancer Research 1998; 17: 1-6

${ }^{10}$ Oliveira, JF, Braga, ACC, Ávila AS, Fonseca LMB, Gutfilen, B Bernardo-Filho, M. Effect of Thuya occidentalis on the labeling of red blood cells and plasma proteins with technetium99m. The Yale Journal of Biology and Medicine 1997; 69: 489-94 